Annals of Warsaw University of Life Sciences - SGGW

Land Reclamation No 47 (3), 2015: 203-210

(Ann. Warsaw Univ. of Life Sci. - SGGW, Land Reclam. 47 (3), 2015)

\title{
Evaluation the vigour of urban green lawn grown under long-term shade conditions by the use of chlorophyll fluorescence technique
}

PIOTR DĄBROWSKI ${ }^{1}$, BOGUMIŁA PAWLUŚKIEWICZ ${ }^{1}$, ANETA H. BACZEWSKA ${ }^{2}$, IZABELA ŁUKASIK ${ }^{3}$, VASILIJ GOLTSEV ${ }^{4}$, HAZEM M. KALAJI ${ }^{3}$

${ }^{1}$ Departament of Environmental Improvement, Warsaw University of Life Sciences - SGGW

${ }^{2}$ Botanical Garden - Center for Biological Diversity Conservation in Powsin, Polish Academy of Sciences

${ }^{3}$ Departament of Plant Physiology, Warsaw University of Life Sciences - SGGW

${ }^{4}$ Departament of Biophysics and Radiobiology, Sofia University St. Kliment Ohridski

\begin{abstract}
Evaluation the vigour of urban green lawn grown under long-term shade conditions by the use of chlorophyll fluorescence technique. Unfavorable light conditions in urban areas are one of the most important cause of inappropriate grass communities condition. The possibility to detect the plant stress caused by shade is an important element in shaping the environment. The answer to following questions: what is the ability to detect the stress caused by shade in chosen lawn varieties of Perennial ryegrass by using the chlorophyll a fluorescence (O-J-I-P test) and which of tested varieties has the best properties to create grasslands in reduced light conditions is the aim of this work. Two-factor experimental micro-plot was conducted with three varieties and three different shadowing variants. Chlorophyll a fluorescence measurements were provided and were compared to leaf density. Our results explored significant difference between selected varieties in the terms of their photosynthetic apparatus adaption to light conditions. During May, all tested varieties were characterized by the rise of all fluorescence curve points under lower light intensity. The largest changes under shade conditions were noticed for the variety 'Taya'. During next months a declining trend of photosynthetic efficiency for this variety was observed. On the basis of our results, we assume that each variety has unique threshold and needs of light intensity.
\end{abstract}

Key words: chlorophyll a fluorescence, OJIP test, unfavorable light conditions, green infrastructure, environment improvement

\section{INTRODUCTION}

The light conditions in urban areas are substantially modified by technical constructions and trees, what leads to the deterioration of grass communities functioning. Under such conditions, the amount of solar energy is reduced, as well as the wavelength spectrum is modified (Bell et al. 2000, Mu et al. 2010). The reduction of photosynthesis rate, accumulation of pigments and leaves elongation are one of the first symptoms of stress (Mu et al. 2010). Subsequently the sodding is reduced. However, the effect of reduced level of solar radiation in longer time, especially on functioning of photosynthetic apparatus of lawn grasses growing urban green areas is still poorly recognized.

Photosynthetically active radiation (PAR) energy absorption by photosynthetic pigments' molecules occurs in the antenna complexes located in the thylakoid membranes (Kalaji et al. 2012, Akhkha et al. 2013). The absorbed energy is then transferred into the excitation form to photosystems I and II (PSI and PSII) reaction centers (RCs), where 
it is used to initiate the photochemical reactions. Some part of energy is lost, mainly is re-emitted as chlorophyll a fluorescence $(\mathrm{ChF})$. The amount of lost energy is an indicator of absorbed light quanta, which are not used in photosynthesis process (Kalaji et al. 2012). OJIP test is based on analysis of the measured signals $\mathrm{ChF}$ and it uses the theory of the energy flow between the various components embedded in the thylakoid membranes. Whereby it is possible to provide information about the functioning and structure of photosynthetic apparatus and allows the detection of stress in plants (Baker and Rosenqvist 2004, Stirbet et al. 2014).

The lawn varieties of Perennial ryegrass (Lolium perenne L.) are commonly used for establishing the lawns in urban areas (Dąbrowski et al. 2013). The answer to following questions: what is the capability of detect the stress caused by shade in tested lawn varieties of Perennial ryegrass by using the chlorophyll a fluorescence measurements (O-J-I-P test) and which of tested variety has the best properties to create grasslands under reduced light conditions is the main aim of this work.

\section{MATERIAL AND METHODS}

The experiment lasted from 20 April 2010 to 24 September 2012 and was established in a vegetation hall at Warsaw University of Life Science - SGGW, in two-factor split-plot system. Each treatment was replicated three times in special boxes $(213 \times 107 \times 15 \mathrm{~cm})$ with permeable bottom. Boxes were divided into nine plots. The seeds were sowed into base (growth medium), which was the mixture of sand $(70 \%)$ and sandy loam (30\%) (Dąbrowski and Pawluśkiewicz 2011). The level of shadowing (the first experimental factor) was expressed by quantity of solar irradiance $\left[\mathrm{W} \cdot \mathrm{m}^{-2}\right]$ : absence of shading - sun (control), halfshade and shadow. The lawn varieties of Perennial ryegrass was the second applied factor. Three varieties: 'Nira' (HBP Sp. z o.o., Poland), 'Henrietta' (Feldsaaten Freudenberger $\mathrm{GmbH} \& \mathrm{Co} \mathrm{Kg}$, Germany) and 'Taya' (DLF-Trifolium Group, Denmark) were tested. The level of shadowing was simulated by layers of agrotextiles, which were constantly imposed on woody frame above the plants (at height of $50 \mathrm{~cm}$ ). Solar irradiance was measured by TM-206 meter (Tenmars, Taiwan). Measurements were performed

TABLE 1. Light conditions in sun, halfshade and shade. Solar irradiance $\left[\mathrm{W} \cdot \mathrm{m}^{-2}\right]$ measured in May, July and September. Measurements were made in this same time as chlorophyll fluorescence measurements

\begin{tabular}{|c|c|c|c|c|c|c|c|c|c|}
\hline \multirow{2}{*}{$\begin{array}{c}\text { Time } \\
\text { of day }\end{array}$} & \multicolumn{4}{|c|}{ May } & \multicolumn{3}{c|}{ July } & \multicolumn{3}{c|}{ September } \\
\cline { 2 - 11 } & sun & halfshade & shade & sun & halfshade & shade & sun & halfshade & shade \\
\hline 8.00 & 325 & 64 & 31 & 246 & 163 & 36 & 153 & 62 & 34 \\
\hline 10.00 & 497 & 273 & 157 & 624 & 257 & 116 & 442 & 184 & 98 \\
\hline 12.00 & 685 & 366 & 249 & 695 & 438 & 198 & 225 & 110 & 78 \\
\hline 14.00 & 687 & 366 & 252 & 545 & 273 & 210 & 241 & 148 & 76 \\
\hline 16.00 & 672 & 282 & 252 & 525 & 233 & 104 & 68 & 38 & 27 \\
\hline
\end{tabular}


in May, July and September 2012, in this same time as chlorophyll $\alpha$ fluorescence measurements (one day in month).

The sward was mowed regularly during study period (the cutting was done when the high of plant was more than $15 \mathrm{~cm}$ ), multiple fertilized Substral 100 was used in $30 \mathrm{~g} \cdot \mathrm{m}^{-2}$ doze, twice during vegetation period $\left(132 \mathrm{~kg} \mathrm{~N} \cdot \mathrm{ha}^{-1}, 30 \mathrm{~kg}\right.$ $\mathrm{P}_{2} \mathrm{O}_{5} \cdot \mathrm{ha}^{-1}, 66 \mathrm{~kg} \mathrm{~K}_{2} \mathrm{O} \cdot \mathrm{ha}^{-1}$ ), irrigated in the case of precipitation absence with $3 \mathrm{~mm} /\left(\mathrm{m}^{-2} \cdot \mathrm{day}^{-1}\right)$. OS5-p fluorymeter (ACD Bioscentific Ltd., United Kingdom) was used to measure the chlorophyll fluorescence signals. Tested intact leaves were adapted in the darkness for $25 \mathrm{~min}$, to pause photosynthesis process. The intensity of the saturation light pulse was $3500 \mu \mathrm{mol} /\left(\mathrm{m}^{2} \cdot \mathrm{s}^{-1}\right)(650 \mathrm{~nm})$. $\mathrm{ChF}$ was measured in middle part of the flag leaf. There were nine repeats in one treatment. There were four main points of fluorescent curve measured: O, J, I and P. Chlorophyll fluorescence measurements were made one time during month. The interval between measurements was about 30 days.

The results from O-J-I-P test were compared to shoot and leaf density valu- ated by evaluation system for turf grasses (Prończuk 1993). This system provides 9 degrees of sodding evaluation, wherein 1 point is $0 \%$ of coverage, 3 points indicate a $20 \%$ of coverage, 5 points are $60 \%, 7$ points are $80 \%$, and 9 points are equal to $100 \%$.

Statistical analyzes were performed by using Statistica ver. 10 program. Analysis of variance (ANOVA) was used to determine the significance of differences between the means, Fischer's test was used as post-hoc test with level of significance $\alpha=0.05$.

\section{RESULTS AND DISCUSION}

During May in the variety 'Nira' it was found that there were a significant increase of the values of 2 points of the chlorophyll fluoresence curve (Fig. 1). Value of O-point was 141 in sun and was separate homogeneus group in comparision to values measured in halfshade (161) and shade (169). The P-point was the secont point, where were significant differences between values measured in sun (552) and in halfshade (15\% higher
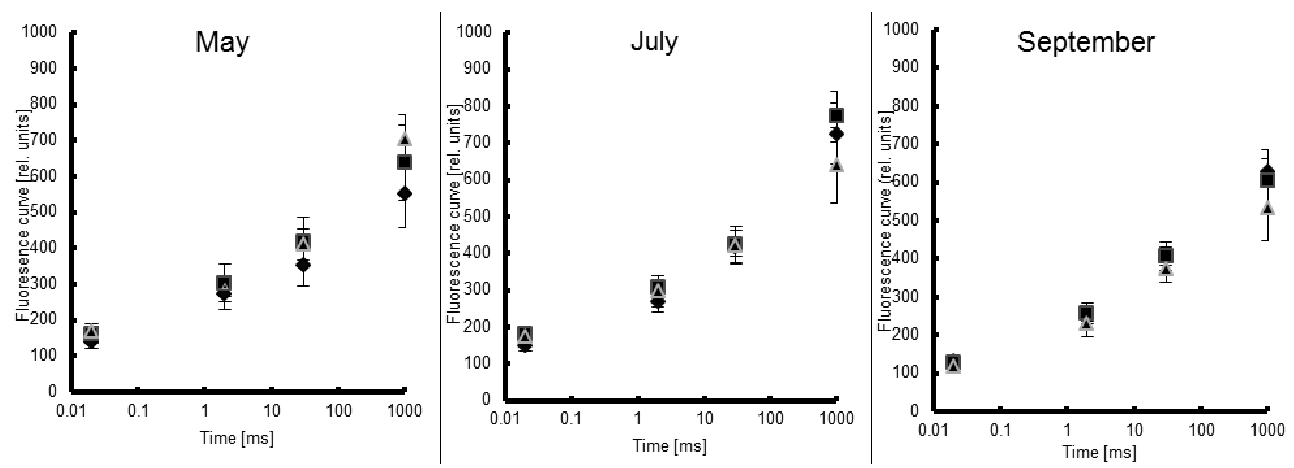

FIGURE 1. The points of O-J-I-P test measured in 'Nira' variety in May, July and September in different light conditions ( $\bullet$ sun, $\boldsymbol{\square}$ halfshade and $\boldsymbol{\Delta}$ shade) 
than in sun) and in shade (27\% higher than in sun). In I and $J$ points there were no significant differences. In July it was confirmed that significant differences between sun and halfshade and shade were in O-point. In other points there were no statistical differences. In September the significant differences were, as well as in July, only in O-point and were between values measured in sun and in shade.

In May in the 'Henrietta' variety it was found that value of O-point measured in sun was 121 and was $20.8 \%$ lower than in halfshade and $47.9 \%$ lower than in shade (Fig. 2). Value of J-point measured in sun was 248 and was $12.7 \%$ lower than in halfshade and $51.9 \%$ lower than in shade. Value of I-point measured in sun was 335 and was $16.8 \%$ lower than in halfshade and $61.1 \%$ lower than in shade. Value of P-point in sun and halfshade were similar, but in shade was significant higher. In the next months, there was a clear equalization of all the points of the curve. Only in July the values of O and $P$ points measured in halfshade were higher than in the sun and shade.

In May, in the the 'Taya' variety it was noted that the value of O-point measured in sun was 153 and was $14.3 \%$ lower than in halfshade and 34.4\% lower than in shade (Fig. 3). The value of
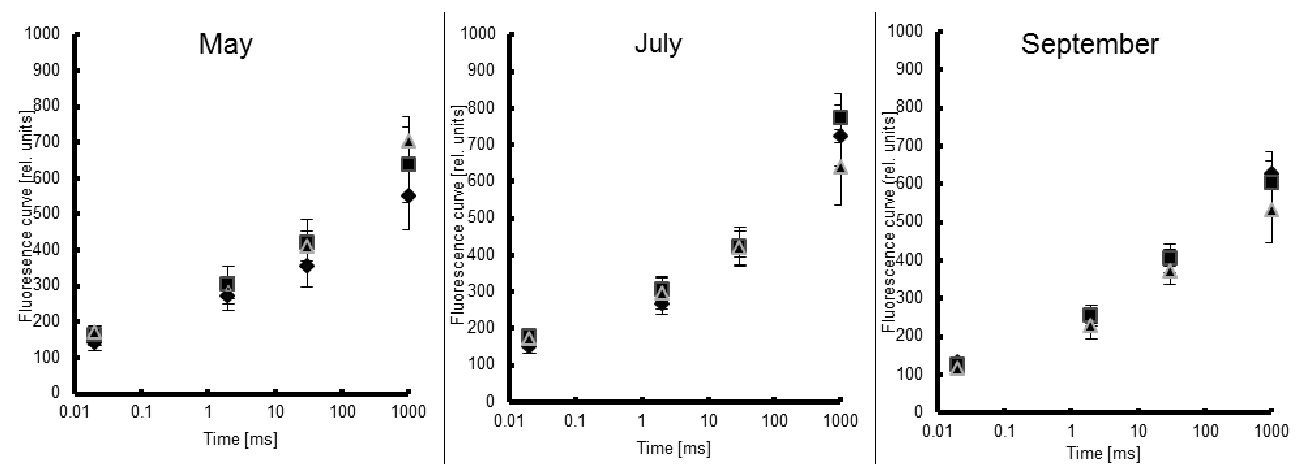

FIGURE 2. The points of O-J-I-P test measured in 'Henrietta' variety in May, July and September in different light conditions ( $\bullet$ sun, $\boldsymbol{\square}$ halfshade and $\boldsymbol{\Delta}$ shade)

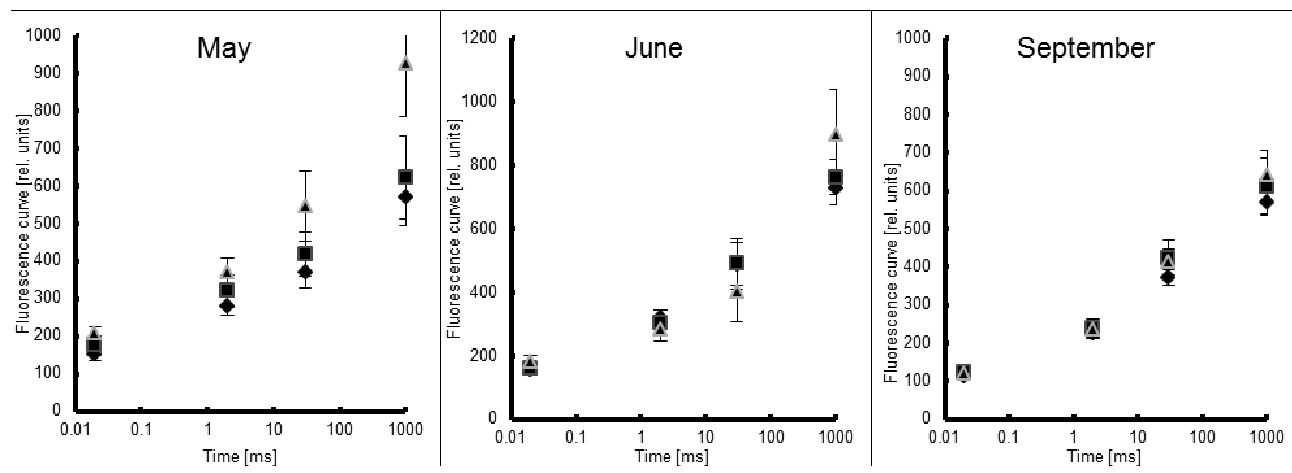

FIGURE 3. The points of O-J-I-P test measured in 'Taya' variety in May, July and September in different light conditions ( $\bullet$ sun, $\boldsymbol{\square}$ halfshade and $\boldsymbol{\Delta}$ shade) 
J-point measured in sun was 280 and was $14.4 \%$ lower than in halfshade and $31.9 \%$ lower than in shade. The value of I-point measured in sun was 370 and was $13.3 \%$ lower than in halfshade and $48.2 \%$ lower than in shade. the value of P-point measured in sun was 569 and was $16.3 \%$ lower than in halfshade and $63 \%$ lower than in shade. The differences beetwen values of all 4 points measured in different light conditions were significant. In next months there was an equalization of values measured in different light conditions. In O-point there were found that in June the value was higher in shadow than in sun and halfshadow. In September there were no differences between values measured in different treatents. In J-point the differences between values measured in sun and shade were significant, but values measured in halfsade were in one homogeneus grup with values measured in sun and shade. 'Taya' was the only variety, which was characterized by differences in the values of J-point measured in the sun and shade in June. In September, as 'Nira, and 'Henrietta', there were no significant differences between values measured in different light conditions. On P-point in July, there were significant differences between values measured in sun and shade, but in September there were no significant differences.

The O-J-I-P test represents translation of the original data to biophysical parameters that quantify the energy flow thought PSII and is very sensitive tool to investigate the photosynthetic apparatus in vivo (Straus et al. 2006). Upon a dark-to-light transition, the fluorescence intensity from chlorophyll increased from a low values (O-point), through two in- termediate points ( $\mathrm{J}$ and $\mathrm{I}$ ) to a maximum values, which is $\mathrm{P}$-point. Changes in the $\mathrm{O}-\mathrm{J}$ phase indicate changes in the photochemical reduction of $Q_{A}$ to $Q_{A}{ }^{-}$(Srivastawa et al. 1997). The increasing of this step has been attributed to the physical separation of the PSII reaction centers from their associated pigment antennae which is resulting in blocked energy transfer to the PSII traps. Increasing of the I-P phase indicate that the plastoquinone (PQ) is not reduced to plastoquinol $\left(\mathrm{PQH}_{2}\right)$, which cause inhibition of electron transfer in the light phase of photosynthesis (Lazár 2009). With time, the induction curves started to converge, which shows the adaptation of plants growing in the shade of the conditions of limited sunlight. Although a fast O-J-I-P test has wide application in environmental studies on the state of the photosynthetic apparatus, it is so far no studies on the effects of long-term shading on O-J-I-P transient. However, there were conducted studies on the effect of short-term shading on O-J-I-P transient performed on barley. Kalaji (2011) shown that 7 days after shading the transient in O-J phase ran much higher than in control. In I-P phase transient ran lower than in control. In opinion of Fu et al. (2012) $F_{0}$ parameter (which is corresponding to $\mathrm{O}-\mathrm{J}$ phase) was increasing in low light intensity, as well as $F_{M}$ parameter (which is corresponding to I-P phase).

The soding was depend on light conditions as well as on variety and time of year (Table 2). In May in sun 'Nira' variety was evaluated at 6 points, 'Henrietta' and 'Taya' varieties were evaluated at 7 points. In halfshade and shade 'Nira' variety was evaluated as 4 . 'Henrietta' variety was evaluated as 6 in halfshade 
TABLE 2. Sodding assessment value [points] of Perennial ryegrass lawn varieties in depending on light conditions (sun, halfshade and shade)

\begin{tabular}{|c|c|c|c|c|}
\hline \multirow{3}{*}{ Month } & \multirow{2}{*}{ Variety } & \multicolumn{3}{|c|}{ Light conditions } \\
\cline { 2 - 5 } & & sun & halfshade & shade \\
\hline \multirow{3}{*}{ May } & 'Nira' & 6 & 4 & 4 \\
\cline { 2 - 5 } & 'Henrietta' & 7 & 6 & 5 \\
\cline { 2 - 5 } & 'Taya' & 7 & 6 & 6 \\
\hline \multirow{3}{*}{ July } & 'Nira' & 6 & 4 & 3 \\
\cline { 2 - 5 } & 'Henrietta' & 7 & 6 & 6 \\
\cline { 2 - 5 } & 'Taya' & 7 & 6 & 3 \\
\hline \multirow{3}{*}{ September } & 'Nira' & 6 & 4 & 4 \\
\cline { 2 - 5 } & 'Henrietta' & 6 & 5 & 5 \\
\cline { 2 - 5 } & 'Taya' & 7 & 6 & 5 \\
\hline
\end{tabular}

and 5 in shade. 'Taya' variety was evaluated as 6 in halfshade and shade. In June there were no change in the surface sodding in the sun and partial shade. In the shadow the soding area of 'Nira' variety was fell. In September, all three varieties were evaluated lower than in the other times of year. In the sun 'Nira' and 'Henrietta' varieties were evaluated as 6 points and 'Taya' variety as 7 points. In halfshade 'Nira' variety was evaluated as 4 points, 'Henrietta' variety as 5 points and 'Taya' as 6 points. In the shade 'Nira' variety was evaluated as 3, 'Henrietta' variety as 4 and 'Taya' as 5 points. In opinion of Mauro et al. (2011), leaf area (as well, as plant dry weight) is significantly affected by shading and time of year. Moreover, in shading there is increasing of shoot/root ratio because of decreased amount of root per plant. The negative influence of shade on leaf area was confirmed also by Dai et al. (2009) and Mirales et al. (2011). Results obtained by Dąbrowski et al. (2013) shown that shading has a strong influence on soding area on parks lawns.

\section{CONCLUSIONS}

Based on the obtained results, it was found that, conditions had a significant impact on the status and functioning of the photosynthetic apparatus in all studied varieties of Perennial ryegrass. Light conditions also had a significant impact on the sodding surface of all tested varieties. With the passage of time, the photosynthetic apparatus was adapting to the conditions of low solar radiation. However, this adaptability to adapting was dependent on the variety. 'Taya' and 'Henrietta' were varieties of the greatest capacity to adapt to the conditions of reduced solar radiation, while variety Nira characterized by a significantly worse ability to adapt. These conclusions were confirmed by the results of the sodding evaluation. 'Taya' and 'Henrietta' varieties were characterized by a greater sodding area than 'Nira' variety. On the basic on analysis of the results it is clear that the O-J-I-P test can be a tool effectively used to determine the effect of shading on individual varieties, and thus, can be 
used for the selection of these varieties for unfavorable light conditions.

\section{REFERENCES}

AKHKHA A., BOUTRAA T., KALAJI H. AHMAD, DĄBROWSKI P. 2013: Chlorophyll fluorescence: a potential selection criterion for drought tolerance in selected durum wheat (Triticum durum Desf.) cultivas. S.O.A.J. NanophotoBioscence 1, $147-156$.

BAKER N.R., ROSENQVIST E. 2004: Applications of chlorophyll fluorescence can improve crop production strategies: an examination of future possibilities. $J$. Exp. Bot. 55, 1607-1621.

BELL G.E., DANNEBERGER T.K., McMAHON M.J. 2000: Spectral irradiance available for turfgrass growth in sun and shade. Crop Sci. 40, 189-195.

DAI Y., SHEN Z., LIU Y., WANG L., HANNAWAY D., LU H. 2009: Effects of shade treatment on the photosynthetic capacity, chlorophyll fluorescence, and chlorophyll content of Tetrastigma hemsleyanum Diels et Gilg. Environ. Exp. Bot. $65,177-182$.

DĄBROWSKI P., PAWLUŚKIEWICZ B. 2011: Wpływ warstwy wierzchniej podłoża o różnej zawartości piasku na rozwój wybranych gazonowych odmian Lolium perenne L. (Influence of soil base with different content of sand for growth of Lolium perenne L). Prz. Nauk. Inż. Ksz. Środ. 51, 27-35 [Eng. summary].

DĄBROWSKI P., PAWLUŚKIEWICZ B., KALAJI H.M., BACZEWSKA A.H. 2013: The effect of light availability on leaf area index, biomass production and plant species composition of park grasslands in Warsaw. Plant soil Environ. 59 (12), 543-548.

FU W., LI P., WU Y. 2012: Effects of different light intensities on chlorophyll fluorescence characteristic and yield in lettuce. Sci. Hortic. 135, 45-51.
KALAJI M.H. 2011: Oddziaływanie abiotycznych czynników stresowych na fluorescencję chlorofilu w roślinach wybranych odmian jęczmienia Hordeum vulgare L. (Influence of abiotic stress factors on chlorophyll fluorescence in selected varieties of barley Hordeum vulgare L. plants). Rozpr. Nauk. i Mon. Nr 387 (hab.) Wyd. SGGW, Warszawa [in Polish].

KALAJI H.M., GOLTSEV V., BOSA K., ALLAKHVERDIEV S.I., STRASSER R.J., GOVINDJEE 2012: Experimental in vivo measurement of light emission in plants: a perspective dedicated to David Walker. Photosynth. Res. 114, 69-96.

LAZÁR D. 2009: Modelling of light-induced chlorophyll $a$ fluorescence rise (O-J-I-P transient) and changes in $820 \mathrm{~nm}$-transmittance signal of photosytnhesis. Photosynthetica 47, 483-498.

MAURO R.P., OCCHIPINTI A., LONGO A.M.G., MAUROMICALE G. 2011: Effects of shading on chlorophyll content, chlorophyll fluorescence and photosynthesis of subterranean clover. J. Agron. Crop Sci. 197, 57-66.

MIRALLES J., MARTÍNEZ-SÁNCHEZ J.J., FRANCOA J.A., BAŃÓN S. 2011: Rhamnus alaternus growth under four simulated shade environments: Morphological, anatomical and physiological responses. Sci. Hortic. 127, 562-570.

MU H., JING D., WOLLENWEBER B., DAI T., JING Q., CAO W. 2010: Long-term low radiation decreases leaf photosynthesis, photochemical efficiency and grain yield in winter wheat. J. Agron. Crop Sci. 196, 38-47.

PROŃCZUK J. 1993: System oceny traw gazonowych (Evaluation system for turf grasses). Biuletyn Instytutu Hodowli i Aklimatyzacji Roślin 186, 127-131 [in Polish].

SRIVASTAVA A., GUISSÉ B., GREPPIN H., STRASSER R.J. 1997: Regulation of antenna structure and electron transport in Photosystem II of Pisum sativum under elevated temperature probed by 
the fast polyphasic chlorophyll $a$ fluorescence transient: OKJIP. Biochimica et Biophysica Acta 1320, 95-106.

STIRBET A., RIZNICHENKO A., YU G., RUBIN A.B. 2014: Govindjee, Modeling Chlorophyll a Fluorescence Transient: Relation to Photosynthesis. Biochemistry (Moscow) 79 (4), 291-323.

STRAUSS A.J., KRÜGER G.H.J., STRASSER R.J., VAN HEERDEN P.D.R. 2006: Ranking of dark tolerance in soyben genotypes probed by the chlorophyll a fluorescence transient O-J-I-P. Environ. Exp. Bot. 56, 147-157.

Streszczenie: Ocena stanu trawników rosnacych $w$ warunkach dlugotrwatego zacienienia za pomoca fluorescencji chlorofilu. Niekorzystne warunki świetlne są jednym z ważniejszych czynników wpływających na instalację i funkcjonowanie trawników na obszarach miejskich. Możliwość wykrywania stresu u roślin spowodowanego cieniem jest ważnym elementem kształtowania środowiska. Odpowiedzi na następujące pytania były głównym celem pracy: jaka jest możliwość wykrywania stresu spowodowanego zacienieniem $\mathrm{u}$ wybranych odmian życicy trwałej za pomocą testu O-J-I-P fluorescencji chlorofilu a oraz która $\mathrm{z}$ badanych odmian ma najlepsze właściwości do tworzenia zadarnień $\mathrm{w}$ warunkach obniżonego promieniowania słonecznego. Został przeprowadzony dwuczynnikowy eksperyment typu splitplot. Dokonano pomiaru fluorescencji chlorofilu oraz oceny powierzchni zadarnienia. Stwierdzo- no istotną różnicę między badanymi odmianami pod względem przystosowania ich aparatu fotosyntezującego do warunków świetlnych. W maju wszystkie badane odmiany charakteryzowały się wzrostem krzywej fluorescencji chlorofilu w warunkach obniżonego promieniowania słonecznego, jednak największe zmiany zostały stwierdzone u odmiany 'Taya'. Na podstawie otrzymanych wyników stwierdzono, że każda odmiana ma inne zdolności adaptacyjne do warunków obniżonego promieniowania.

Stowa kluczowe: fluorescencja chlorofilu a, test O-J-I-P, niekorzystne warunki słoneczne, zielona infrastruktura, kształtowanie środowiska

\section{Authors' addresses:}

Piotr Dąbrowski, Bogumiła Pawluśkiewicz

Katedra Kształtowania Środowiska, Wydział Budownictwa i Inżynierii Środowiska SGGW ul. Nowoursynowska 159, 02-779 Warszawa Poland e-mail: piotr_dabrowski@sggw.pl

Aneta H. Baczewska

PAN Ogród botaniczny CZRB - Powsin ul. Prawdziwka 2, 02-973 Warszawa, Poland

Izabela Łukasik, Hazem M. Kalaji

Katedra Fizjologii Roślin, Wydział Rolnictwa i Biologii SGGW

ul. Nowoursynowska 159, 02-779 Warszawa

Poland.

Vasilij Goltsev

Departament of Biophysics and Radiobiology

Sofia University St. Kliment Ohridski

8 Dragan Tzankov blvd, 1164 Sofia, Bulgaria 